\title{
Restoration of ecological and geological systems of disturbed lands of South Primorye
}

\author{
Alexander Belov ${ }^{1,2}$, Natalia Repsh $^{1,2, *}$, Svetlana Berseneva ${ }^{2}$, Elena Demidenko ${ }^{2}$, Vasilisa \\ Landyk $^{1}$, and Veronika Lomova ${ }^{1}$ \\ ${ }^{1}$ Far Eastern Federal University, ul. Sukhanova, 8, 690090, Vladivostok, Primorsky Krai, Russia \\ ${ }^{2}$ Primorskaya State Academy of Agriculture, Blucher pr., 44, 692510, Ussuriysk, Primorsky Krai, \\ Russia
}

\begin{abstract}
The restoration of plant ecosystems of brown coal dumps in the stepped areas of South Primorye occurs in two ways: 1) by reclamation; 2) by overgrowing. Only $2 \%$ of disturbed lands undergo reclamation, the rest is overgrowth. Spontaneous restoration of ground cover is the least promising, since it does not provide the formation of stable successions. The way out of this situation is the controlled contagious introduction of diasporas of species typical for a given habitat in combination with the necessary microflora.
\end{abstract}

\section{Introduction}

The ongoing deterioration of the quality of the natural environment in mining areas around the world, including in Russia, necessitates the search for ways and methods to overcome the negative consequences of human intervention in the functioning of natural systems, including ecological and geological systems.

One of the main ways to restore the fertility of lands, aimed at restoring flora and fauna after carrying out technical reclamation, is a biological method of reclamation [1].

The beginning of biological land reclamation, which was industrialized, can be considered 1926, when the reclamation of land disturbed by mining in the state of Indiana (USA) began [2]. In Europe and the USA, biological reclamation began to develop in the prewar years. In the post-war period, great importance was attached to the biological reclamation of disturbed lands in the industrialized countries of the former Soviet bloc: the German Democratic Republic, Czechoslovak Socialist Republic, People's Republic of Poland, People's Republic of Bulgaria, People's Republic of Hungary, and also in England and German Federal Republic. In these countries, reclamation consisted in the creation of recreational forests, where aero-sowing, seeding on steep slopes with hydraulic washing, and manual and mechanized planting were widely practiced. Great importance was given to the selection of species of tree-shrub plants that are most resistant to difficult environmental conditions. The selection of species was carried out on the basis of observations of the natural overgrowing of dumps [3]. The advantage of Western and American programs was the close

\footnotetext{
*Corresponding author: repsh_78@mail.ru
} 
linking of reclamation with work plans for the protection of soil and water within the boundaries of special reclamation areas.

In Russia in 1912, the first experiments on the cultivation of agricultural plants were carried out in areas of abandoned peat mining in the territory of the present Vladimir region.

Reclamation work in our country began in the 50-60s of the 20th century with the development of peat mines for forestry purposes in the north and northwest of the European part of the country [4]. The Russian State Standard GOST 17.5.1.03-78 "Classification of uncovering and enclosing rocks for biological land reclamation" has been developed with the aim of designing and implementing land restoration in practice.

Currently, the number of disturbed lands in Russia is 792,700.5 ha; restored land 59397.5 ha (table 1, fig. 1).

Table 1. The number of disturbed, depleted and restored land in connection with non-agricultural activities.

\begin{tabular}{|c|c|c|c|c|c|c|c|}
\hline & 2012 & 2013 & 2014 & 2015 & 2016 & 2017 & 2018 \\
\hline \multicolumn{8}{|c|}{ Russian Federation } \\
\hline Disturbed (total), ha & $\begin{array}{l}47174 \\
0.9\end{array}$ & $\begin{array}{l}72332 \\
0.2\end{array}$ & $\begin{array}{l}89266 \\
8.1\end{array}$ & $\begin{array}{l}87349 \\
1.9\end{array}$ & $\begin{array}{l}13310 \\
97.3\end{array}$ & $\begin{array}{l}12424 \\
16.3\end{array}$ & $\begin{array}{l}79270 \\
0.5\end{array}$ \\
\hline Disturbed per year, ha & $\begin{array}{l}10972 \\
5.8\end{array}$ & $\begin{array}{l}13712 \\
5.9\end{array}$ & $\begin{array}{l}15272 \\
2.4\end{array}$ & $\begin{array}{l}13623 \\
2.4\end{array}$ & $\begin{array}{l}17846 \\
4.0\end{array}$ & $\begin{array}{l}25624 \\
2.2\end{array}$ & $\begin{array}{l}11948 \\
1.3\end{array}$ \\
\hline $\begin{array}{l}\text { Depleted from the total area } \\
\text { of disturbed lands for the } \\
\text { year, ha }\end{array}$ & $\begin{array}{l}89486 \\
.5\end{array}$ & $\begin{array}{l}81524 \\
.3\end{array}$ & $\begin{array}{l}99448 \\
.1\end{array}$ & $\begin{array}{l}97608 \\
.4\end{array}$ & $\begin{array}{l}11138 \\
7.5\end{array}$ & $\begin{array}{l}17376 \\
1.5\end{array}$ & $\begin{array}{l}69305 . \\
9\end{array}$ \\
\hline Restored per year, ha & $\begin{array}{l}75597 \\
.7 \\
(1.6 \% \\
)\end{array}$ & $\begin{array}{l}74651 \\
.4 \\
(10.3 \\
\%)\end{array}$ & $\begin{array}{l}84388 \\
.5 \\
(9.5 \% \\
)\end{array}$ & $\begin{array}{l}68552 \\
.4 \\
(9.9 \% \\
)\end{array}$ & $\begin{array}{l}92051 \\
.8 \\
(6.9 \% \\
)\end{array}$ & $\begin{array}{l}28672 \\
.9 \\
(7.9 \% \\
)\end{array}$ & $\begin{array}{l}59397 . \\
5 \\
(7.5 \%)\end{array}$ \\
\hline \multicolumn{8}{|c|}{ Primorsky Krai } \\
\hline Disturbed (total), ha & $\begin{array}{l}4650 . \\
7\end{array}$ & $\begin{array}{l}6836 . \\
5\end{array}$ & $\begin{array}{l}7378 . \\
1\end{array}$ & $\begin{array}{l}8152 . \\
2\end{array}$ & $\begin{array}{l}8312 . \\
5\end{array}$ & $\begin{array}{l}4772 . \\
5\end{array}$ & 8532.9 \\
\hline Disturbed per year, ha & 117.7 & 300.1 & 255.6 & 129.3 & 210.4 & 91.5 & 266.9 \\
\hline $\begin{array}{l}\text { Depleted from the total area } \\
\text { of disturbed lands for the } \\
\text { year, ha }\end{array}$ & 10.0 & 24.36 & 189.1 & 8.0 & 37.6 & 22.1 & 287.3 \\
\hline Restored per year, ha & $\begin{array}{l}10.0 \\
(0.2 \% \\
\end{array}$ & $\begin{array}{l}364.1 \\
(5.3 \% \\
)\end{array}$ & $\begin{array}{l}318.6 \\
(4.3 \% \\
)\end{array}$ & $\begin{array}{l}83.64 \\
(1.03 \\
\%)\end{array}$ & $\begin{array}{l}45.6 \\
(0.5 \% \\
\end{array}$ & $\begin{array}{l}14.5 \\
(0.3 \% \\
\end{array}$ & $\begin{array}{l}152.1 \\
(1.8 \%)\end{array}$ \\
\hline
\end{tabular}

Note. According to the Federal Service for Supervision of Natural Resources of the Russian Federation [5]. 


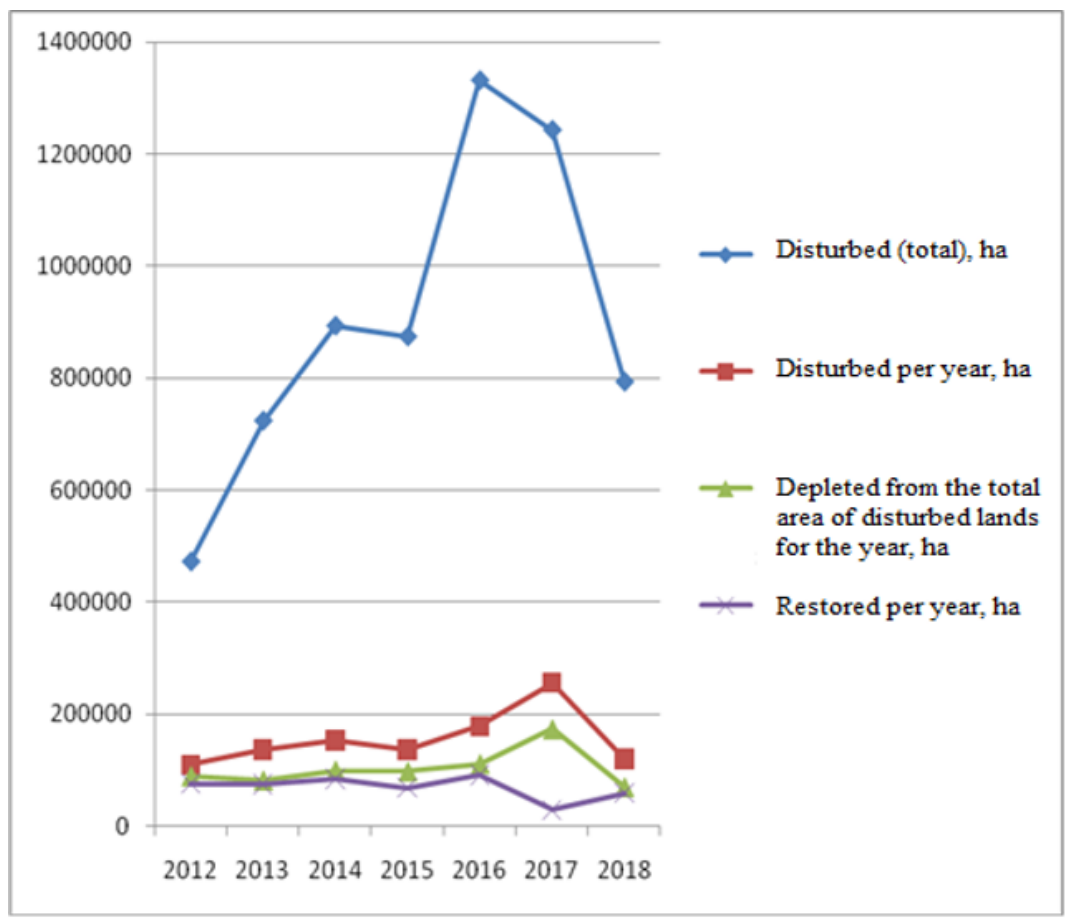

Fig. 1. The amount of disturbed, depleted and restored land in connection with non-agricultural activities (Russian Federation).

The territory of the Primorsky Krai was chosen for our study. This area is located in the south of the Far Eastern Federal District of the Russian Federation. The nature of the Primorsky Krai is extremely diverse. It combines elements of the natural zones of the temperate and subtropical zones, therefore, plants native to different countries of the world can be found there.

On the territory of the region, 8532.9 hectares of land are currently in need of restoration, and 152.1 hectares are restored, which is $1.8 \%$ (Fig. 2). The growth of the economy in the Primorsky Krai determines the rapid development of energy industry. The main source of energy for the Primorsky Krai is local brown coal, which is mined open-pit. As a result of open-pit coal mining, huge areas of coal dumps are formed, the reclamation of which, due to lack of funds, is almost not carried out. The dumps have a complex relief and almost do not undergo landscape reconstruction. Classical restoration is extremely expensive and laborintensive, therefore alternative, less energy and resource-intensive methods of reclamation of the ground cover and restoration of ecosystems are necessary. 


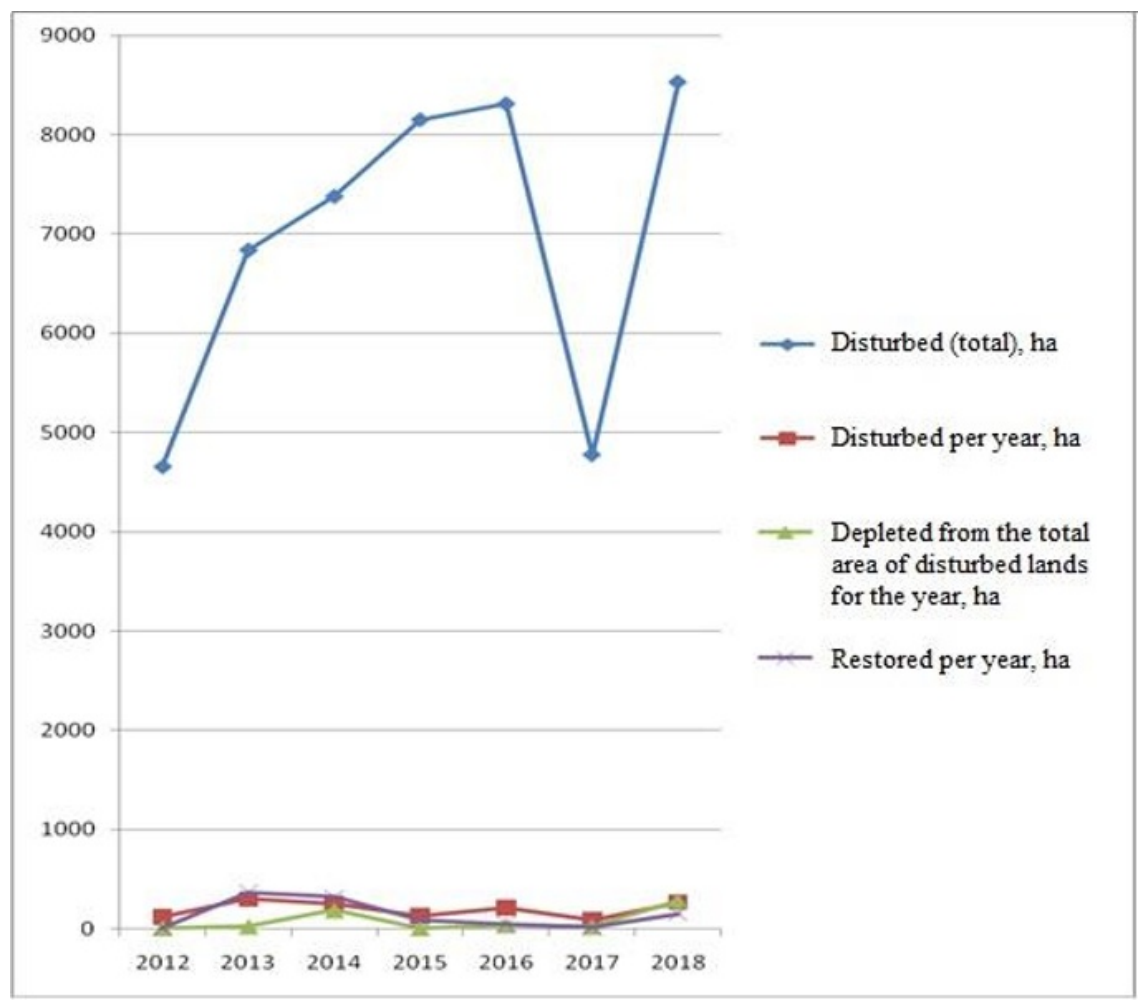

Fig. 2. The amount of disturbed, depleted and restored land in connection with non-agricultural activities (Primorsky Krai).

\section{Purpose of the study}

The purpose of the study is to study the ecological situation at different stages and in different conditions of restoration of disturbed landscapes of the Primorsky Krai and to identify the existing patterns of their vegetation cover dynamics. To consider ways of spontaneous restoration of the ground cover of disturbed lands in open pits for brown coal mining.

\section{Materials and methods}

Overgrowth of dumps of the Novoshakhtinsky deposit in the Mikhailovsky district of Primorsky Krai is the material of this study (geographical location: 44.000945; 132.160289) (Fig. 3). 


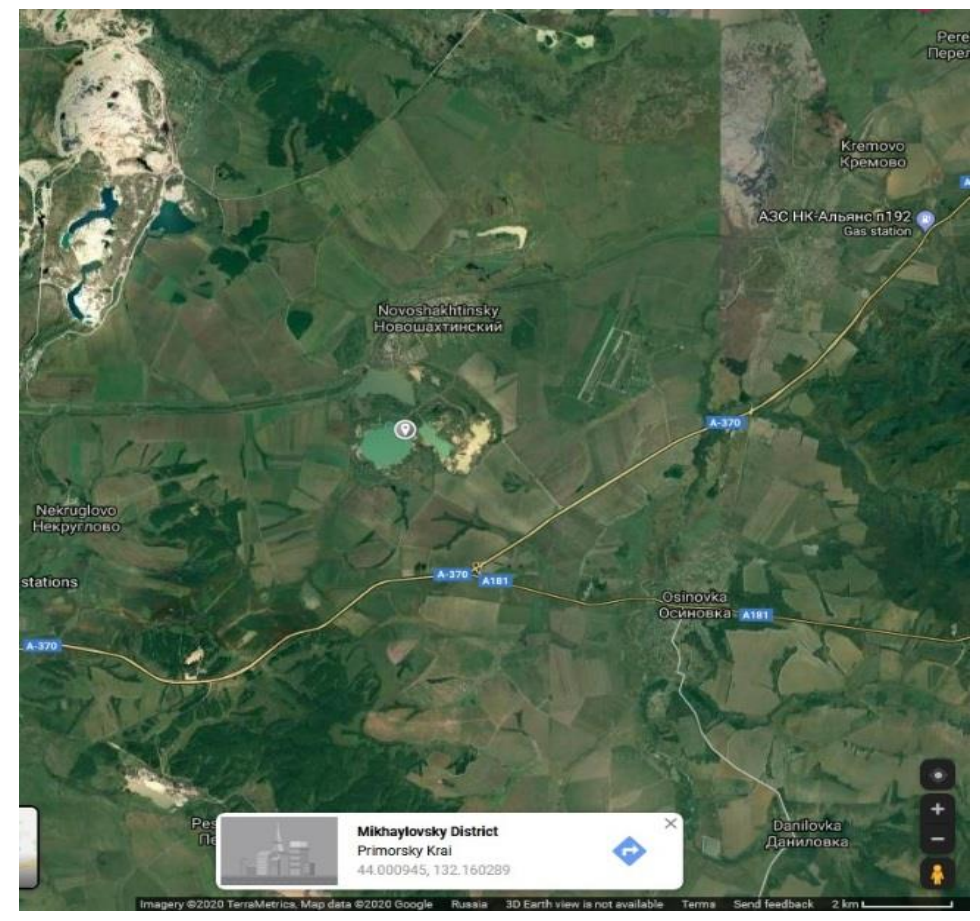

Fig. 3. The location of the study area of brown coal dumps, Novoshakhtinsky village, Mikhailovsky district of Primorsky Krai.

Observations were carried out from 2006 to the present, using mainly ocular estimation and abundance estimation on the Drude scale.

\section{Results and discussion}

According to the data obtained, the formation of vegetation on brown coal dumps in stepped sections can occur in two ways:

1. Primary formation of herbaceous ruderal plant communities with subsequent introduction of woody vegetation.

2. Primary formation of herbaceous ruderal plant communities with their subsequent destruction as a result of erosion processes. At the site of ruined ruderal communities, woody plants gradually consolidate the soil, and the secondary formation of the ground cover from herbaceous ruderal plants occurs.

In the main zone, the dumps are inhabited by grassy vegetation consisting of species of the genus Artemisia L., Calamagrostis Adans, Phragmites communis a small admixture of family species Leguminosae. The woody component is represented by single trees or small scattered groups of species of the genus Salix L. and Phragmites communis (table 2, 3).

None of the existing structures for the restoration of vegetation is fully consistent with the full restoration of vegetation. In the best case, small-component, flawed communities are formed, including 15 to 20 species.

During the formation of herbaceous ruderal plant communities, the most unpretentious woody components are introduced - Salix rorida, S. schwerinii, Populus davidiana, P. maximoviczii, Betula mandshurica. These phytocenoses are unstable and do not contribute to the accumulation of organic matter in the soil. 
Table 2. Herbaceous components of overgrowth of brown dumps.

\begin{tabular}{|l|c|}
\hline \multicolumn{1}{|c|}{ Specie } & \multicolumn{1}{|c|}{$\begin{array}{c}\text { Abundance } \\
\text { (according to Drude) }\end{array}$} \\
\hline 1. Calamagrostis epigeios (L.) Roth. & Cop. 1 \\
\hline 2. C. Langsdorffii Trin. & Sol. \\
\hline 3. Vicia amoena Fish & Sp. \\
\hline 4. V. cracca L. & Cop. 3 \\
\hline 5. Trifolium pratense L. & Cop. 2 \\
\hline 6. T. campestre Scheb. & Cop. 2 \\
\hline 7. T. Repens L. & Sol. \\
\hline 8. Cilycine ussuriensis Rgl. et Maack. & Sol. \\
\hline 9. Artemisia scoparia Wladst. et Kit & Cop. 3 \\
\hline 10. A. gmelinii Web. ex Stechm. & Cop. 3 \\
\hline 11. A. rubripes Nakai.) & Cop. 3 \\
\hline 12. Phragmites communis Trin. & Cop. 3 \\
\hline
\end{tabular}

Table 3. Woody plants of brown dumps.

\begin{tabular}{|l|c|}
\hline \multicolumn{1}{|c|}{ Specie } & $\begin{array}{c}\text { Abundance } \\
\text { (according to Drude) }\end{array}$ \\
\hline 1. Salix rorida Laksch & Soc. \\
\hline 2. S. schwerinii E. Wolf & Un. \\
\hline 3. Populus davidiana Dode & Sol. \\
\hline 4. P. maximoviczii A. Henry & Sol. \\
\hline 5. Betula mandshurica (Rge.) Nakai & Sol. \\
\hline 6. Hippophae rhamnoides L. & Un. \\
\hline
\end{tabular}

In the second case, exclusively sparse groups of Salix rorida are formed, which have a strong allelopathic effect that impedes the introduction of other tree-shrub species.

In our opinion, the weedy overgrowth of the stepped sections of slag dumps is the least promising in terms of restoration of the ground cover, since it provides an opportunity for wind erosion for a long time. The pioneering components of the weedy overgrowth are various species of Artemisia L, which deplete the primary organic matter of the soil and inhibit the development of soil microflora [6].

We consider a way out of the current situation to be the controlled induced population of disturbed habitats by the diasporas of the most typical plant species in this area in combination with the microflora characteristic of these species. For example, for nitrogen accumulators, nodule bacteria or phosphobacteria, characteristic of them, can be used to efficiently assimilate phosphorus compounds for other species.

The establishment of diasporas on fairly steep slopes of brown coal deposits involves a change in their relief. For a long time, it was believed that this requires a change in the macro or at least the microrelief. According to our numerous observations, this requires only insignificant interference with landscape reconstruction, for example, water and wind erosion, which creates a heterogeneity of the nanorelief. Also, the recreational load contributes to this.

The most effective for the formation of the ground cover of disturbed habitats is the contagious introduction of diasporas of species of consort-forming agents together with the concomitant microflora, which allows the formation of separate foci of spots of ground vegetation, which subsequently effectively close. 


\section{Conclusions}

1) The overgrowth of brown coal dumps occurs in various ways - the formation of smallleaved tree plantations, the formation of weedy vegetation, followed by the introduction of Leguminosae Juss.

2) Spontaneous overgrowth does not ensure the formation of stable successions allowing the inclusion of disturbed habitats in the natural cycle of natural phytocenoses.

\section{Recommendations}

The long history of the formation of anthropocenoses suggests that a person should be attentive to the trends in the formation of natural biocenoses and, disturbing them, follow the example of minimal intervention in their restoration. When restoring disturbed habitats, it is necessary to take into account the surrounding biocenoses and introduce elements that do not contradict the natural environment. Intervention in the structure of the landscape and microbocenosis should be minimal, based on the climatic and geological conditions.

\section{References}

1. V.K. Tokhtar, N.A. Martynova, V.I. Petina, M.A. Petina, Materials of the VI International Scientific Conference: Environmental Management Issues and the Environmental Situation in European Russia and Neighboring Countries, 403-406 (2015)

2. I.V. Gurina, Reclamation (Publishing House of NGMA, Novocherkassk, 2008)

3. L.V. Motorina, The experience of reclamation of landscapes disturbed by industry in the USSR and foreign countries (Moscow, 1975)

4. G.A. Zaitseva, Forest Reclamation (Forestry, Moscow, 1997)

5. The official website of the Federal Service for Supervision of Natural Resources of the Russian Federation, http://25.rpn.gov.ru/opendata/7703381225-tprecultiv

6. A.N. Belov, S.A. Bersenyova, O.N. Ivus, G.A. Belova, Systematic Reviews in Pharmacy 11(3), $538-543$ (2020) 